University of Louisville

ThinkIR: The University of Louisville's Institutional Repository

$5-2014$

\title{
Imperial masculinities from late Victorianism to early global modernism.
}

Michael Anthony Phillips

University of Louisville

Follow this and additional works at: https://ir.library.louisville.edu/honors

Part of the English Language and Literature Commons

\section{Recommended Citation}

Phillips, Michael Anthony, "Imperial masculinities from late Victorianism to early global modernism." (2014). College of Arts \& Sciences Senior Honors Theses. Paper 53.

http://doi.org/10.18297/honors/53

This Senior Honors Thesis is brought to you for free and open access by the College of Arts \& Sciences at ThinkIR: The University of Louisville's Institutional Repository. It has been accepted for inclusion in College of Arts \& Sciences Senior Honors Theses by an authorized administrator of ThinkIR: The University of Louisville's Institutional Repository. This title appears here courtesy of the author, who has retained all other copyrights. For more information, please contact thinkir@louisville.edu. 
Imperial Masculinities

From Late Victorianism to Early and Global Modernism

By

Michael Anthony Phillips

Submitted in partial fulfillment of the requirements

for Graduation magna cum laude

and

Graduation with Honors from the Department of English

University of Louisville

May, 2014 


\section{Table of Contents}

Introductory Statements.................................................. 3

Kipling's Man: The Victorian Ideal........................................ 8

Conrad's Oppositional Platform in Marlow's Subversive Masculinity................. 14

Banjo and Ray's Utopia: Marseille as Setting for Modernist Masculine Expression....... 25

Wilson Harris' Colonized Colonizer: An Exploration into Post Imperial Masculinities.... 35

Closing Remarks....................................................... 45

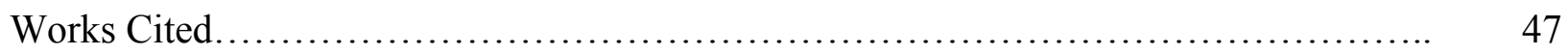




\section{Introductory Statements}

Victorian gender constructions were not exclusive to England at the turn of the twentieth century. No, Europe and its colonies in the Americas and Africa largely functioned with the same social understanding, revolving around one central motivating theme: empire. As a result of this focus on expansion, many of the gender expectations found in most of the nineteenth century and early twentieth century are determined based on imperial sentiments. What this project will discuss at length is the way these gendered constructions transitioned into the modern period based on representative literary works. Additionally, the project seeks to answer what effects empire had on masculinity as well as how the general image of maleness was affected during the transition from Victorianism into early and global modernism. My overall contribution to the conversation of masculinity from late Victorian literature to early and global modernist literature lies in my intention to present the unique perspective of victims of imperialism, the colonized, or at least those affected by colonialism, as that perspective pertains masculine expression.

Exploration into this subject requires a contextual look at the period, which extends from the late nineteenth century into the middle of the twentieth. As gender theorists have declared gender as a performative practice, this project looks to detail the manner in which masculinity has historically been performed and the transitional nature attached to it. Additionally, I will monitor and explicate the ways masculinity decentralized from the singular imperialist definition applied by Victorians to the more inclusive, broad one given by modernist writers, who appear as victims of colonial tendencies.

In order to explain how these masculine traditions were successfully challenged, a definition of masculinity is necessary. Simply put, masculinity is the societal expectation 
applied to performances that are typically associated with maleness or actions seemingly exclusive to men. To give a Victorian gender expectation derived from Coventry Patmore's infamous "Angel in the House" poem, whereas feminine expression is limited to the private, domestic sphere, masculine expression lies in the public, commercial sphere. Further, Kenneth Clatterbaugh states that masculinity, "is a set of behaviors, attitudes, and conditions that are generally found in the men of an identifiable group" (Clatterbaugh 3). This helpful definition applies to the study of this project, in that the paradigm of the Victorian imperialist was a widely embraced ideal, and the modernist writers explored here react to those behaviors, attitudes and conditions coming out of that ideal in a masculine context.

Beginning, I will analyze the works of the late Victorian writer Rudyard Kipling in order to deliver a clear illustration of masculinity in the context of a booming imperial nation. His poem "The White Man's Burden" provides the defining characteristics of the ideal colonist and man, and his version of masculinity, which was popularly considered by Britain at the time, is conveyed entirely in relation to expansion. Using the language of Clatterbaugh, the behaviors, attitudes and conditions ascribed to men socially and economically revolved almost solely on expansion. The poem presents a racist and masculinist view of the role of men, and the pronounced standard is a disturbing one. To reinforce this definition of maleness in the context of empire, his short story "The Man Who Would Be King" will be dissected. The goal of this particular analysis is to explore the ways Kipling attempts to motivate potential British colonists, as he believes no other nation, no other type of men are indeed capable of settling foreign and native lands.

From these macho, hyper-masculine guidelines for maleness comes an early modernist reaction in the form of Joseph Conrad's Heart of Darkness. Conrad in this text reacts to many 
different Victorian injustices, including the role of men in an imperial context. His response, though not as explicitly stated as later modernist reactions, is one of direct critique: Kipling's idealized image of imperial masculinity is attacked by the feminized, nativized and queer storyteller in Marlow. Conrad's conception of masculinity as a result of empire is one of panicked uncertainty, and he subtly delivers a haunting account that questions many Victorian institutions. His narrator, though operating widely within the imperial framework aboard the Nellie, occupies the position of a storyteller not so much victimized by colonialism, but one that is certainly affected by it. Though controversial in a contemporary setting, this text still provides a foundation on which other modernist writers can explore and discover updated versions of masculinity.

Working from this kind of foundation, Claude McKay delivers a wholly modernist representation of maleness in the twentieth century in consequence of empire, which at this point is beginning to constrict. In the liberal European port city of Marseille, McKay's Banjo presents an array of masculine expressions, concluding that maleness cannot be defined or explained singularly. Through his dissection of his two primary characters in both Banjo and Ray, he announces that many different forms of masculinity can exist and be considered equally, resulting in the modernist harmonious, utopian setting in Marseille. Both Ray and Banjo respond to Victorian imperial masculine expectations from a victimized perspective: they have first-hand witnessed the exploitative nature of colonialism, and they are eager to critique the institution from different angles.

As a representative global modernist text, Wilson Harris' 1960 novel Palace of the Peacock fully debunks Victorian masculinity, among various other social institutions, in the crew and specifically the character Donne. This non-linear, dense surrealist text provides a similar 
conclusion to Banjo, in that masculinity should be considered outside of the singular context of imperialism and instead considered wholly. The Palace in the novel explains this sentiment, and Harris is motivated to dismantle lingering Victorian masculinist social structures. Additionally, Harris provides characters that operate out of a unique position, particularly in Donne. Though he is, with the rest of his crew, a victim of imperialism in many respects, he still wishes to exploit his fellow Guyana natives. In this problematic narrative, Harris offers his critique of empire and Victorian masculinity from the position of a victim of imperialism.

This project looks to explore the historical contexts in which these texts derive and provide a framework for the way we consider masculinity today. By delivering a detailed analysis of the history of the gendered concept, the transition from Victorian ethics surrounding the subject into early and global modernist will seem necessary. One cannot ignore the travesties of imperialism throughout the nineteenth century into the twentieth, and the motivations and consequences of those who committed the atrocities necessitates attention. Whereas the concept of Victorian masculinity, or the image of maleness, was defined singularly as the idealized, exaggeratedly macho imperialist, the modernist reaction points out the faults of this exploitative, violent illustration. Modernism, as a literary and social movement through representative writers, explains how that one image is a problematic one and that many varying perceptions of maleness exist.

Global modernism is a field still undergoing many compositional alterations, and with this project I look to focus on the ways it is taking shape. One of the main, though not necessary, tenets of it comes from the background of the writer. Wilson Harris is from Guyana prominently writing in the 1960s and 70s, and though he appears some 50 years after the height of high modernism, he is still a modernist writer in a global context. He writes critically of modernity 
and, most importantly, critiques the still dominant ideals of Victorianism. Claude McKay has similar origins, coming from Haiti and largely writing of an American experience, yet he, too, occupies the position of a modernist writer because of his geographical, temporal placement in addition to the content of his novels. With a novel as unique as Banjo, which tells the story of an American expatriate hoboing in Marseille, globally modernist overtones are present.

While Kipling has illustrated the expectations applied to masculine expression in Victorian colonial era, Conrad, McKay and Harris all respond to these expectations separately. As Conrad's reaction is biting yet subdued, both McKay and Harris employ his critique as a springboard for their own distinct responses. By exploring the various ways in which these modernist writers present the perspectives of those affected or victimized by imperialism, I will show the ways in which the nature of masculinity has transitioned in a literary and historical context. My intention in writing on these rather different authors is to illuminate the contributions of global modernist texts, as they, like early modernist pieces, critique Victorian standards and ideals, and I will illustrate how these writers do it from a victimized position. 


\section{Kipling's Man: The Victorian Ideal}

Rudyard Kipling offers the clearest view of imperial masculinity in a mid-to-late Victorian context. In his poem "The White Man's Burden," he explicitly states the characteristics and requirements of colonizing Victorian men, marking the trying difficulties and honorable expectations surrounding the plight of expansion. Similarly, in his short story "The Man Who Would Be King," he provides an account that motivates male British readers into taking up the call to colonizing, as he implies no other people are as capable as the English, specifically. His concept of masculinity denotes a white, conservative, exploitative, chivalrous and upstanding British man, and though he may not be responsible for inventing the concept, he certainly gives life to it by defining it clearly.

In “The White Man’s Burden,” Kipling defines clearly social and institutional masculine gender constructions within Victorian England, then experiencing the golden years of its empire. The first line, "Take up the white man's burden -" (Kipling 1), repeats in every stanza and makes the poem racially charged. He characterizes the ideal Victorian male as white and responsible, in a paternal sense, for the unwanted obligation of colonizing land and people. Kipling in this light praises the men about to be sent to these exotic and heathen lands, relaying their task is a difficult, demanding and supposedly necessary one.

Providing the justification for capitalist, imperial rule in a Machiavellian manner, he reminds the men of England that war is necessary to accomplish peace as a means to an end. Additionally, he notes the imperial imperative for every agent of expansion to bring times of plenty and health, since the colonized natives were seen as disadvantaged, primitive, childlike and, primarily, non-white. 
Kipling's Victorian approach to imperialism in this respect demands a certain kind of masculinity. For the Victorian male to be truly masculine, he needs to display authority over lesser beings. In the context of this poem, the "new-caught, sullen peoples, / Half-devil and halfchild" (7-8) are the freshly conquered inhabitants whose humanity is stripped for the purpose of both exploitation through free market capitalism as well as for the satisfaction of the conquerors. These colonized people are not considered human beings by the colonizer, justifying using these natives as slaves and unfairly treated workers. The Victorian male is tasked with governing these people, who are treated more as subjects or animals.

Kipling uses Biblical rhetoric to further rationalize colonization: the cautionary line "Watch Sloth and heathen Folly" (23) stands as a testament to Christian, specifically Anglican, ideology. These descriptors can be safely assigned to indigenous peoples, who Kipling warns will undermine the necessary actions of the colonists. Including one of the seven deadly sins in his warning is intentional, as Kipling declares that, not only are these native inhabitants prone to committing sin, they are also lazy to an intense degree. Kipling's colonist, in this light, is tasked with motivating these conquered people to produce commodities or cultivate the settled lands by whatever means necessary.

Further, he looks to motivate the archetypal imperialist claiming, despite, as Kipling would argue, their admirable and necessary intention of stripping the colonized of their culture and replacing it with British civilization, they will be met with resistance. The Victorian man must continue to fulfill his duty, citing the act of sacrifice as an ideal every colonist must perform. This sort of persuasion using the language of Western Christianity and the Bible allows Kipling to fully relate to the dominant culture of mainstream England, which was highly conservative in this period. Finally, the tone with which to deal with these resisting natives is 
not one of compassion or empathy but, rather, of firmness and brutality, suggesting the response to this resistance should be a violent, masculine one.

Kipling's Victorian version of masculinity reaches its climax in the final stanza, producing an uneasy and mostly upsetting effect. With the call for colonial men "to search your manhood" (53) to achieve "The judgment of your peers!" (56), he demonstrates his logic behind Victorian expansion: the central goal of the exploitation of others through imperial action is the approval of other imperialists. With decorations of a "lightly proffered laurel," (51) which is essentially a testament to the successes of the bullish Roman Empire, and "ungrudged praise" (52), this rousing call for the men of England to take up the task of expansion is a somewhat effective one, despite appearing entirely ethically contradictory.

This ethical contradiction is a confusing undertaking, as Kipling employs powerful, masculinist rhetoric to make these hyper masculine expectations the norm. Robert Hampson enters this conversation when he states the goals for the aspiring British imperialist in this sort of colonial environment: "He attempts to project a masculinist ideology within, and as part of, an imperialist vision. However, the attempt to assert a military model of masculinity is constantly subverted from within $[\ldots]$, disquieting elements of sadism, and the haunting sense that male separateness might be a limitation rather than a strength" (Hampson 7). Kipling creates a masculine climate in which forcible imposition for the sake of spreading British, capitalist civilization is not only revered but, also, mandatory.

Soon after the publication of "The White Man's Burden," a number of global events surround the impending and certain collapse of the British Empire. Around the turn of the twentieth century, the empire faced a host of problems: the total disorganization of officiating in Africa, the eve of Irish independence from England as a result of many bloody uprisings, and the 
blossoming of Indian independence sentiments. The historian Bernard Porter writes of the time, "But in 1900 the empire was coming to seem under threat" (Porter 24), detailing the gradual process of which Britain's authority in its colonies began to wane. The time of the writing of this poem produces a rather confusing effect, as it marks the ongoing accomplishments of an empire that is actually about to crumble. Additionally, the way the Victorian empire is about to constrict coincides with how the concept of masculinity will similarly dissolve.

Some 11 years before the publication of “The White Man’s Burden,” Kipling's short story "The Man Who Would Be King" offers similar commentary. The content of the tale is broadly open-ended, but in the context of masculinity in imperialism, however, it can be said that the story is a cautionary one, an overarching guideline of what not to do when colonizing natives. Instead, he wishes to give a detailed telling of what happens when the wrong kind of people become colonizers.

The narrator informs the reader throughout that Dravot and Carnehan, the chief imperialists of the story, are morally bankrupt. Prior to embarking on their journey to their desired kingdom in Kafiristan and Afghanistan, they made their livings essentially blackmailing Indian officials when not engaging in some sort of manual labor where native Indians were exploited grossly. Additionally, they are plainly rude and entitled, presumably stemming from their being from the civilized West living in the colonized East. Not entirely of pure English descent, Dravot's red beard suggests he is of Irish heritage. What Kipling is trying to assert, in this light, is that the formerly colonized (in this instance the Irish) are not suited morally to colonize other lands or peoples. This sentiment reflects the message of “The White Man's Burden," in that Kipling believes the only people suitable to adequately and sustainably colonize is white, English male imperialists. 
These men do not have the moral English caliber to colonize. A scholar of Kipling, Raymond Brebach discusses his motivation in creating such characters: "The frame narrator describes them with an irony which serves both to distance them from the reader and to judge their plan as the hare-brained scheme of men operating way out of their depth" (Brebach 77). Dravot and Carnehan in this respect are dichotomized with the typical Victorian, masculine settler, with the former two representing the general negatives in expansion and the latter ideal surmising its broad positives.

Because these men are not British, thereby not as hierarchically important, they express moral transgressions that lead to their violent and expected demise. Dravot does not buckle under the pressures of willfully exploiting other people but, instead, shows his true self when he betrays the original contract, signed by both him and Carnehan, that stipulated he would not marry one of the native women. The contract explicitly states this sort of action is strictly forbidden, as the colonizers will be shown as human rather than as gods. Dravot breaks it not for the benefit of the colonized, his partner, or the empire, but, rather, he breaks it because he is entirely self-interested. These men are not adequate colonists, and Kipling explains subtly why colonizing should be left to the English.

"The Man Who Would Be King" reflects much of the rhetoric found in "The White Man's Burden" is presented here. When speaking of India, the narrator, admittedly the most respectable character in the account, still fosters a condescending resentment with his description of the settled area: "Native States were created by Providence in order to supply picturesque scenery, tigers, and tall-writing. They are the dark places of the earth, full of unimaginable cruelty, touching the Railway and the Telegraph on one side, and, on the other, the days of Harun al-Raschid" (Kipling 1855). Many characteristic Kipling rhetorical markers appear here, such as 
biblical allusions, references to exoticism, and intense critique of native peoples and uncivilized places. In the former sentence, positive clichéd and hackneyed images of India are conjured to the credit of the Christian God; in the latter, hedonistic and frightening details are attributed to this place, now untouched and unattended to by the same God.

This sort of biblical rhetorical use emerges again when Carnehan is telling the correspondent his tale, especially when he states, "Then all the people comes down and shouts like the devil and all, and Dravot says, --'Go and dig the land, and be fruitful and multiply,' which they did, though they didn't understand" (1867). Kipling in this instance shows how these men are not typical, justified Victorian men trying to expand the English Empire through the use of God's word. Instead, they are claiming verses of the bible as their own, acting as gods themselves. Though both manifestations of expansion are especially paternalistic towards colonized peoples, Dravot and Carnehan seem slightly sadistic in their push for settling these natives.

Kipling's ideal Victorian imperialist masculinities were popularly held ones even after the emergence of modernist writers who directly responded to them. With the persistence of these modernist writers in candidly publicizing the horrors of colonization, for both the colonized and the colonizer, these masculinist expectations would begin to wane along with Victorian conservativism, generally, throughout the twentieth century. As the next section details, Joseph Conrad explores many of the highlighted or appreciated themes discussed here in order to critique them. 


\section{Conrad's Oppositional Platform in Marlow's Subversive Masculinity}

Joseph Conrad in his 1899 controversial novella Heart of Darkness criticizes the popular image of maleness derived from Kipling with the hopes of debunking it. Despite not being immediately and entirely successful in this approach to imperial masculinity, his legacy would allow his literary successors to appropriately fight this dominant portrait of masculinity. $\mathrm{He}$ primarily criticizes the inhumane effects of empire as a result of British and European expansion. His protagonist Marlow stands as a personification of this oppositional sentiment. Admittedly, Conrad receives a lot of criticism for providing an account that does not appear to threaten or outwardly challenge colonialism, with many scholars claiming his potentially racist language further puts down settled and colonized peoples. However, through his inclusion of a feminized narrator in Marlow, uniquely anti-colonial colonists in Kurtz, the manager, and the crew aboard the Nellie, and the bleak descriptions of both the conquerors and the conquered, the text subtly undermines imperialist masculinity in a subtle and contemporaneously subversive approach.

After the introduction of the characters of the crew by the narrator, Conrad wastes no time in delivering Marlow's thoughts on the institution of empire. In the preface to his tale Marlow indicates the horrors surrounding imperial dominance: "“He [the colonist] has to live in the midst of the incomprehensible, which is also detestable. And it has a fascination, too, that goes to work upon him. The fascination of the abomination - you know. Imagine the growing regrets, the longing to escape, the powerless disgust, the surrender, the hate"' (Conrad 1956). The details of what this "abomination" (1956), which can also be interchanged with the term "empire," is capable of on the psyche of the colonist wanes on Marlow, who discusses the negative aspects of Roman occupation in England almost some 1500 years prior. Marlow's historical consciousness allows him to draw parallels between his current imperial climate with a 
Roman context that perished in part because of over-expansion. This connection is significant, as it paints the British as a formerly colonized and barbaric people.

In emphasizing Roman imperial endeavors, Marlow parallels the conditions in that ancient hyper-masculine, imperial society with the expectations applied to him by the British Empire. He sees past the expansion-centered social environment of England and dissects the "fascination" with imperialism present at the time. The last sentence of the passage, which reads, "Imagine the growing regrets, the longing to escape, the powerless disgust, the surrender, the hate"' (Conrad 1956), clarifies the effects of empire on the psychology of the colonist, directly conflicting with ideals of Victorian masculinity proposed by Kipling, who justified imperial tendencies with capitalist and religious rhetoric. The Victorian man cannot show weakness: by admitting these psychological terrors in a confession, Marlow successfully breaks from the tradition constructed by Kipling.

Conrad identifies the deleterious effects of empire at the turn of the twentieth century, when Victorian ideals and gender expectations are still dominant. The social climate of this transitional time in England called for the best and brightest gentlemen to make the ultimate sacrifice of spreading British civilization to savage natives of conquered or soon-to-beconquered lands, as is clearly displayed in Kipling's “The White Man's Burden” and other Victorian texts. Marlow does not represent this masculine tradition. Instead, he paints himself through his tale as weary and conflicted about the process of colonization.

Marlow assumes the position of a feminized colonial narrator. This exploration of Marlow as a feminized narrator is not an uncommon one, and many scholars have addressed the subject. Commenting on the position of Marlow as anti-masculinist in Victorian society, Andrew Roberts argues that, "In inviting the reader to empathize with [...] male characters who 
temporarily occupy a 'feminized' position, the fiction offers some critical purchase on these structures of exploitation, without ever fully analysing or stepping outside them" (Roberts 1212). Marlow refrains from explicitly critiquing empire. Instead, he implies the effects of it through dehumanizing first-hand accounts, descriptions of his own dreadful feelings amidst these accounts, and overall pessimism. He knows these "structures of exploitation" exist but does not employ visceral, biting language in his tale. Rather, he utilizes the focus on unknown feeling and observation ("abomination," "powerless disgust," and, as it recurs throughout the tale, "darkness") as a means of critiquing the dominant, colonial society.

An additional element to Marlow's feminine narration is worth examining: the abounding undertones of the text cast him as a queer narrator. What drives this argument is the obvious and inexplicable obsession Marlow has with Kurtz. Though this ongoing obsession can be interpreted as an intellectual curiosity, it can also just as easily be labeled a romantic one. The implications of this romantic connection appear throughout Marlow's journey as he renders his tale to his audience, seemingly in passing. Describing the motion and direction of the stream on which his boat is moving, he states, "For me, it crawled towards Kurtz - exclusively" (Conrad 58). Marlow at this point does not describe how the river leads to knowledge of imperialism or a better understanding of human nature and its effects on colonialism. No, he describes the river in relation to Kurtz, who in this context appears more as an object of romantic desire than a monetary objective, which he initially is. Another instance that marks his longing to see Kurtz arises when he discusses the way he measures relative distance: "Sometimes I would pick out a tree a little way ahead to measure our progress towards Kurtz by, but I lost it invariably before we got abreast" (Conrad 64). Again, Marlow's fascination with Kurtz is depicted as a romantic and obsessive one. Marlow at the beginning of his journey considers him an object of desire 
additionally because he appears to be the perfect imperialist. When he mourns Kurtz's death, he is not only mourning the death of a potentially loved one: he mourns the loss of the imperial ideal, the colonial dream.

A substantial portion of scholarship is devoted to the relationship between Marlow and Kurtz being a potentially homosexual one. Many describe it in terms already mentioned, and Richard J. Ruppel offers an explanation for the circumstances surrounding their subtle romance. He discusses the colonial realm: "In a world without women, the possibility of intense and intensely satisfying relationships between men is obviously increased" (Ruppel 39). This examination of the context of colonial Africa does not necessarily wholly describe the homosexual relation between these two characters, but it provides an adequate foundation for the existence of one. He cites a specific example where Marlow is outwardly defensive about his fascination with Kurtz with the statement, "When Marlow expresses excessive grief over what he believed was the death of Kurtz, at least one member of his audience feels that he has overstepped normal homosocial bonds. We know this because Marlow immediately responds to the panic and placates his audience by introducing 'the girl,' Kurtz's Intended” (37). What this means in the grander context of the novel is that not only is Marlow aware of his overwhelming interest in Kurtz, the entire crew aboard the Nellie picks up on Marlow's defensiveness.

The relationship between Marlow and Kurtz is suggestively homosexual. A final instance in the novel that can help substantiate this claim appears near its conclusion, when Marlow informs Kurtz's Intended of Kurtz's demise. Rather than being honest and telling her his true last words, he lies to her. Though this dishonesty has been hotly debated, a reason for his lying could rest in his desire to retain a form of intimacy between Kurtz and him. Revealing one's last words to another is admittedly a rather tender and poignant action, and it seems he is 
interested, at least at that point in Marlow's life, in holding onto that information. He reserves this bit of Kurtz for himself, denying others truth about Kurtz's life and death. What makes this existence of a potentially homosexual obsession relevant to this project is that it goes against the conservative guidelines Victorians like Kipling set in defining masculinity in the context of imperialism. The best and brightest of England are to have seemingly very courtly heterosexual desires, and with Marlow as the storyteller, this firm conservative definition is distorted and liberalized.

In addition to being both a feminized and queer narrator, Marlow represents anti-colonial sentiments in the way that he appears exoticized throughout the novel. Specifically, in one instance early in the novel, the narrator aboard the Nellie describes him as "yellow" (Conrad 1957). The scholar P.K. Saha poses Marlow as an anti-colonist and an exoticized figure. In this scenario, he discusses the interesting descriptors surrounding Marlow painting him to be like the Buddha. Saha states, "If Marlow is a flawed hero, the Buddhist perspective becomes especially important for understanding him as a product of the nineteenth century, sharing in its guilt, yet attempting to transcend it" (Saha 156), implying the reason for Marlow sharing his tale is of a spiritual, mystical variety. Additionally, this quote observes how Marlow before, during, and after his travels, was aware of the atrocities occurring because of imperial expansion and, as a result, was ashamed for being involved as well as being cognizant of the exploitative conditions. Another tenet of Buddhism is education, and Marlow appears to quell his guilt on the matter by sharing his knowledge.

In comparing Marlow to the Buddha, Saha claims, "The Buddha himself tended to view people in terms of the limitations of their contexts rather than in terms of inflated heroism” (156). Marlow, in his own tale from his own experiences, is a coward. He does not necessarily 
try to hide behind any exaggerations or fabrications: he details his encounters in the Congo and his less than heroic reactions to specific instances. In this light, he creates greater distance from the accepted and dominant definition of Victorian masculinity, as he expresses no interest in painting himself as macho or brawny; his details of himself seem honest. Though it appears a haunted one, Marlow after completing his tale inhabits some sort of peace. Whereas Buddhists support the act of finding internal peace as a means of rejecting desires and temptation, Marlow, too, has at least become comfortable in himself enough to discuss adequately and eloquently the events of his voyage in the Congo without depicting himself in a more macho or robust light.

Acting as a contrast to the feminized, queer and exoticized Marlow, Kurtz appears as a pervasive character. He is a man who went to Africa with great influence, great promise, and great ambition, who became nativized and resultantly went rogue. He held all of the characteristics of the ideal Victorian colonist prior to immersing himself in colonization. Conrad is intentional in presenting this information to the reader to challenge dominant masculinist tropes of his time. Because Kurtz dies near the end of Marlow's tale, Conrad makes clear he thinks this is the common fate of even the most successful imperialists. Andrea White proceeds with relevant commentary: "the work exposed the machinery behind the apparent naturalness and inevitability of the imperial endeavour and made visible the conqueror's face hidden behind the mask of a civilizing mission's protestations of benevolence" (White 198). From this passage, Conrad's goal to unmask the intentions behind colonialism is evident. Additionally, Conrad appears interested in unmasking the difference between ideology and practice in colonial affairs, and through his documentation of Kurtz, that unmasking successfully occurs.

Kurtz in this unmasked light is the most successful imperialist in terms of shelling out commodities, in terms of making profits for his company. Despite this success, he has sacrificed 
his humanity entirely. Continuing in this analysis on Kurtz as a character, the Victorian British critic Joseph A. Kestner explores the effects of this unmasking on masculinity. His stance on the issue appears when he details how the text, "is the interrogation of a male paradigm, the transmission of Marlow's novel to the first narrator, and the corrosive effect of men on each other and their inability to establish a male identity in an existential hell" (Kestner 106-7). This multifaceted thesis presents a lot to digest. The Victorian "male paradigm" Kestner refers to is the one propagated by literary and social figures like Kipling, resonating with the guidelines and expectations laid out in “The White Man's Burden.” Kestner's thesis, as it applies to imperial masculinities, calls to reconsider how Marlow is affected by the other males he experiences on his journey. As psychology was being focused on increasingly more heavily at the turn of the twentieth century, it makes sense that Conrad would present men suffering from psychological terrors. Though Conrad establishes immediately that the manager of the station is potentially sociopathic, a man totally lacking a conscience, the character of Kurtz deserves a second look. His internal ailment is inflicted by events happening in Africa. Imperialism is responsible for Kurtz's mental anguish and eventual death: prior to entering the imperial market, he was a man of great influence, constitution, and fortitude. After having experiencing the horrors of the Congo, though, the grotesqueries witnessed while colonizing are responsible for his complete change of character. Kestner continues with this language in detailing how, "Marlow recognizes that 'all Europe contributed to the making of Kurtz' by its imperial ambition" (109). Much like Marlow will never be able to forget the atrocities he has witnessed on his voyage, Kurtz similarly, and obviously much more intensely, is wholly affected by immersion in the colonial trade. 
Though capitalism and monetary gain are the primary incentives for expansionist and imperialist tendencies, proving one's masculinity certainly holds some sort of importance in the process. Kestner comes to his conclusion on the text, stating, "the constant references to 'darkness' in the novella assume one additional connotation from the setting, that the male rite of passage is a dense journey through psychological darknesses" (111). This position poses a rather intriguing circumstance: an additional motivating factor for imperialism is proving one's manhood. Also, with Kipling's Victorian expectations already being so demanding and psychologically taxing, the modernist reaction to these demands makes sense. Conservative masculine values were pressed greatly by Victorians like Kipling, and because of the conservative nature of their ideals surrounding masculinity and empire, modernists of the early twentieth century responded with more liberal and humane interpretations of masculine ethics.

Finally, Marlow's depiction of Kurtz's painting expresses Conrad's critique of the civilizing of Africa. The illustration appears as, "representing a woman, draped and blindfolded, carrying a lighted torch. The background was somber - almost black. The movement of the woman was stately, and the effect of the torchlight on the face was sinister" (Conrad 40). Interpretively, the reader can gather that the torchlight in the painting is acting symbolically as civilization, or at least the spreading of it. What is interesting about the artwork is the woman who is "blindfolded" (40): typically, the woman holding scales and symbolizing justice is blindfolded, serving as an indicator in how justice is blind. In this context, though, those responsible for spreading civilization, the colonizers, are blinded. This unique detail informs the reader that Kurtz is aware of how he is blindly spreading Western ideals. By discussing how, "the effect of the torchlight on the face was sinister" (40), Marlow interprets that the colonizer is 
not fully equipped to spread civilization as he is unaware of the ideals of civilization and is entirely blinded from it.

In addition to depicting Kurtz grimly and bluntly, Marlow details the other characters he encounters with a similar bite. Marlow's description of the manager of the station in extreme disarray helps solidify the glaring contrast between imperial ideology and Conrad's frank depiction of how empire really exists in Africa. Through his depiction, the reader can gather that this administrator represents the kind of people running colonies and trade stations in Africa. Statements like, "He had no genius for organizing, for initiative, or for order even... no learning, and no intelligence" (Conrad 34), suggest to the reader how incompetent these officials are and how they are not, incidentally, empire's brightest. Moreover, Marlow indicates these people are potentially sociopathic: "But he was great. He was great by this little thing that it was impossible to tell what could control such a man. He never gave that secret away. Perhaps there was nothing within him" (35). This manager's coldness, his inability to empathize with the conquered and dominated natives makes him, for Conrad, the perfect candidate to oversee the extraction of ivory in the Congo. He discusses an alternate reason for his success in Africa in the maintenance of his perfect health. Whereas most in his position had died, likely from sickness or from guilt, he has successfully gotten over any threatening illnesses and has been able to ignore the atrocities taking place before him.

To understand Marlow's dissection of the colonists he encounters on his journey, one must first become acquainted with the ideology of empire historically. Andrea White enters this conversation of how Conrad handles imperial masculinities with her analysis of Heart of Darkness, and other works of his, in a specifically historical context. Her thesis regarding the matter is perfectly summed with the passage, 
"While it might have been more difficult for empire's agents to understand the totality, cloaked as it was in ideology, it was possible for someone in Conrad's unique position to see beyond the burgeoning rhetoric of the empire's civilizing mission that accompanied and legitimated the endeavour and to notice, as he soon did, the disparity between that discourse and the actuality of grabbing 'for the sake of what could be got"' (White 183).

Marlow's conflict as a narrator, with this information, makes sense. Though he refrains from explicitly challenging expansion and expansionist tendencies, he still points out inherent faults in them. The ideologies Marlow and Conrad are opposing are the clear masculinist expectations applied by Victorians like Kipling and John Ruskin. None of the men Marlow encounters on his journey down the Congo embody the valiant, gallant and chivalrous qualities Kipling outlines. Instead, he interacts with characters like the manager and the rogue Kurtz, who additionally stand as contrasts to the archetypal Victorian colonist.

As other agents of expansion, Conrad provides the reader additional critical commentary through the crew aboard the Nellie. Marlow calls for them to imagine the horrors of empire he has witnessed. This crew consists of Victorian middle-class men, including the captain, the lawyer, the accountant, the narrator (presumed to be a writer of some sort) and Marlow, acting as archetypal agents of expansion. Kestner addresses this presence of Victorian types of men in stating how they represent an "an all-male microcosmic community aboard the yawl Nellie" (Kestner 107). Rather than highlighting the successes and triumphs of the colonist, he announces the psychological hardships he must now continually face, perpetually, as a result of living in this masculinist setting that encourages the domination of others. He must surrender to the requirements thrust on him by Victorianism. He must spread hate. 
Certainly, this account of masculinity is not the most liberal even for its time. The content of the novel stands in opposition to much of what conservative Victorians like Kipling outlined for masculinity in imperial contexts. Each of the colonizing characters in the novel in Marlow, Kurtz, the manager of the company and the crew aboard the Nellie represent intensely anti-colonial attitudes, some more explicitly than others. The significance of the oppositional nature of Conrad in his characters allowed later modernists to expand on protests against conservative Victorian renderings of masculinity. In the context of this project as a whole, Conrad stands as an interesting middle-point in his criticism of empire and its effects on masculinity. While Kipling stands as a particularly conservative representative and the later definitive modernists in McKay and Harris stand as particularly liberal, Conrad occupies a unique pivotal point between the two camps, seeming to actively contribute to both thought processes. 
Banjo and Ray's Utopia: Marseille as Setting for Modernist Masculine Expression Because of Conrad's initial approach in critiquing Victorian idealism as it pertained to masculinity, Claude McKay with his 1929 novel Banjo takes the criticism one step further and addresses the issue in a modernist context. He does not deal with material as graphically as Conrad but still confronts Kipling's unfair Victorian masculinist definition given to maleness. The modernist image of maleness he offers is an unclear one: the male characters in the text all conduct their lives separately and distinctly, and that variation in holding masculine principles appears to be deliberate. Rather than expressing a clear, unified definition of masculinity like the one Kipling posed to the Victorians of England, McKay provides an account that details several different forms of masculinity of varying and conflicting degrees. In the character Banjo, the reader discovers McKay involves the more Americanized idealization of masculinity coined by literary and social figures like Jack London and Teddy Roosevelt, who promoted rugged individuality and uninhibited self-expression. Alternately, Ray represents a postcolonial manifestation of masculinity. He has internalized the overwhelmingly negative effects of empire personally, and has attempted to adopt Banjo's carefree and attachment-free lifestyle. His attempt inevitably fails, though, as he dwells on issues of his own identity in terms of masculine expression. Both characters, with their opposing views of masculine expression and maleness, represent McKay's complex rendering of gender roles in a modernist, post imperial context.

The setting of the novel being Marseille is important when taking into account McKay's modernist reporting on masculinity after the general critique of many Victorian ideals. The French port town displays a uniquely diverse collection of people across social, ethnic, and national barriers. Frequently throughout the tale, the narrator discusses the numerous representatives of American, European, African and Asian nations all coexisting in what seems 
to be a modernist harmony. In one particular instance, McKay ties a comment on masculinity to this diaspora when describing the actions of Banjo and his newly-made friends: "Having finished eating, the men came off the deck, all friendly vagabonds again. Squabbling and scuffling came natural to them, like eating and drinking, dancing and bawdying, and did not have any bad effect upon the general spirit of their comradeship" (McKay 42). This passage offers McKay's updated view of and approach to masculinity. Where Victorians in the nineteenth and early twentieth century valued decency, chivalry, and a commitment to a national cause or plight as cherished masculine characteristics, McKay sees maleness manifested in the opposite. In McKay’s modernist report, men indulge in selfish, earthly experiences for their own sake, much to the probably dismay of Victorian stalwarts.

Moving specifically to the character Ray, the text presents his complicated thought process from the perspective of one victimized by empire. Ray struggles with the concepts of patriotism and nationalism as masculine, privileged constructions. He opposes and deplores the masculine expectations applied to him, specifically the animalistic acts humans are forced to commit because of a misplaced admiration for a state. By describing nationhood as "a monstrous system for plundering weaker peoples" (137), he inflects his diatribe against masculinity in nationalism with imperial implications, appearing to attack the still accepted and somewhat idealized image of man as colonist illustrated by Kipling and other lingering Victorians.

The second half of the passage demonstrates Ray's veneration for Banjo's vagabond lifestyle and manifestation of masculinity. Sharing this similarity, both Banjo and Ray enjoy their nomadic lifestyles for experiencing and adapting to other cultures rather than forcing their own customs onto others. Granted, the issue of identity arises, as Ray, a Haitian expatriate, and 
Banjo, a native and expatriate of the United States South, are fairly representative the black diaspora of Marseilles depicted in the novel. Further, he claims the patriot, having overt masculine connotations, is known less for his enthusiasm for his country and, rather, more for his closed-mindedness. Because this notion seems a direct response to assigned, prescribed masculine Victorian expectations, Ray assumes a feminized position of narration. I want to be careful at this point in presenting the femininity of Ray. His actions are not necessarily feminine because of their oppositional nature to the masculine expectations of the time but, rather, because his actions reflect contextually common feminine practices. McKay plays on the feminine stereotypes Ray exhibits, such as his nurturing, caring nature as a means of illuminating a different kind of masculinity. Rather than limiting his self-expression to entirely masculine traits, he instead blends his masculinity with his femininity, producing a balance at which Kipling would likely scoff and from which Conrad would likely shy away. This situation highlights the divergence between Ray and Banjo as representations of masculinity.

Ray, in addition to critiquing the masculine trope of tying oneself to national pride, explores and nearly obsesses over the issue of race in the modern world. Even in Marseille, a highly liberal city throughout most of its history as a port town home to many sailors, Ray identifies a racial hierarchy. For him, race and masculinity appear to be equally contentious and problematic, as he believes Victorian imperial social constructs favor white males. Though this heteropatriarchal system exists in our contemporary world, comparatively, the situation then was much more difficult to accept, especially for Ray. In the text, when speaking of the typical tolerance of sailors, he states, "Except the white American sailor. He sees everything, but he learns nothing" (194). As the United States at this time in history was increasingly becoming 
considered an imperial power, Ray associates this intentional closed-mindedness and deliberate ignorance with the act of colonizing.

Continuing in how Ray feels of empire and how it affects his maleness, Ray establishes sarcastically his feelings of imperial tendencies when he engages the university student in the café near the novel's completion. When the student marks the highlights of French civilization, speaking specifically of French tolerance toward minorities and people of color, Ray becomes enraged. He inflects sarcasm into his diatribe, stating, "You Europeans have a wonderful record in Africa and I suppose you're all proud of it" (275). This instance reflects again how Ray feels about nationalist motivations for expansion. Ray, as an academic, is aware of the horrors and atrocities that have taken place and that are currently taking place in Africa as a direct result of European colonization. The French student is offended by Ray's perspective on the matter and storms off, pleasing Ray. This satisfaction implies another facet of McKay's definition of masculinity, which appears as a direct protest to Victorian imperial ideals. Bridget T. Chalk contributes to this conversation with the comment, "Cultural and national pride was constructed and maintained through the traffic of colonial goods and the accompanying implication of their origins as backward and definitively other to the urban centers of the French imperial nation” (Chalk 364). In this particular instance in the café, Ray appears to realize this general feeling, having interacted with many of the products of and newcomers to the Ditch. The French student, conversely, acts subconsciously in his consideration of Ray and other foreigners like him. In this context, Ray is made out to be the "other," similar to the manner which he is treated when he is unlawfully and brutally arrested in the novel. While Victorians shaped their ideal image of maleness around supporting and expanding empire, modernists, like McKay, shape their image 
of masculinity around the critique and protest of colonization. Ray's behavior in his meeting with the student reflects McKay's focused sentiment.

Many of Ray's intellectual conversations in the novel either revolve around the issue of masculinity or, at least, mention it in the context of the contracting imperial world. When speaking of the role of women in the world, which seems frustratingly parochial in the contemporary world, offers insight into lingering Victorian concepts of gender roles. He argues that women are subordinate to men, still, in this hyper masculine, expansion-minded world, and that women are just as objectified and commodified as the lands and resources being conquered. He supplements this argument with the statement that "The days of chivalry are stone dead, and the world today is too enlightened about sex to be fooled by white or black propaganda" (206). Though Ray inevitably had problems with the concept of chivalry historically as a racist, masculinist and exploitative institution, in the context of this quote he makes clear again his direct, modernist response to masculine gender constructions. For him, Victorian ideals of masculinity, as well as those historically preceding them, too, have run their course and cannot exist in this modern world.

In order to consider the character Banjo, the divergence between his intensely independent lifestyle and Ray’s careful academic composition is worth exploring, as it explains McKay's unclear yet encompassing view of manhood. Commenting on this obvious binary, the scholar Gary Holcomb observes, "Where Banjo is formally unschooled, Ray is educated; where Banjo is a primitive, Ray is a modern; where Banjo seeks his pleasure of the flesh with the opposite sex, Ray is same-sex oriented. And both are black. The two protagonists, if that is the best locution for the male lead dispersion, appear to construct an absolute binary opposition" (Holcomb 155). All of the conditions are present for different, almost opposite, manifestations 
of masculinity to exist between the two. The level of thought, though, separates the two definitively: Ray observes and analyzes the interactions and happenings of The Ditch, while Banjo instinctively acts. Though capable of deep thought, he prefers instead to adapt and survive in his current state, whatever or wherever that might be.

As Ray’s struggle with maleness stems from his dizzying self-awareness and analysis of his nationhood, Banjo opposes Victorian masculinity not so much through careful thought but, rather, his actions. His responses are not as explicit as Ray's, but are seen more through his expression and apathy. His characterization early on paints a clear image of what McKay thinks of his masculine self expression: "His life was a dream of vagabondage that he was perpetually pursuing and realizing in odd ways, always incomplete but never unsatisfactory" (McKay 11). This carefree, duty-free way conducting himself is a direct response to the manner in which ideal colonists as defined by Kipling would act. While the typical imperialist is driven entirely by a cause, with nationalist, religious, or masculinist motivations behind that cause, Banjo simply lives his life for his own experiential benefit. As he declares later in the section, "'Don't care how I falls, may be evah so long a drop, but it's always on mah feets"' (17), he does not fear failure on a societal level or in a cultural context. Rather, he is comfortable with his actions and with himself as his expectations are set personally. While Kipling's Victorian man constructs his goals based on imperial motivations, McKay's twentieth century modernist man sets himself free from these constrictions.

Other characters in the novel notice his atypical behavior. As the temporarily upset Latnah proclaims in her diatribe of Banjo, "He no man. He no good. He no got no pride of race. Me give him sleep. Me give him eat. Me give him love. Me give him money for go buy that thing. Even my money he took and went off laughing and sailor-rocking like that, away from me 
to spread strange joy" (169). Not only does this quote establish a further distinction between Ray and Banjo, with the former concerning himself entirely with race issues and the latter seeming to ignore them, it also serves as an adequate marker for discussing Banjo's care-free, vagabond lifestyle. Commenting on Banjo's conduct and the general lifestyle of those inhabiting the Ditch, Bridget T. Chalk states, "The freedom of Banjo and his fellow wanderers from jobs, families, and the responsibilities of citizenship seems to elude the fixed categories created and maintained by racist oppression in the early twentieth century and to offer alternative ways of making do in circuits of nationalism, capitalism, and imperialism" (Chalk 358). Banjo in this setting not only makes do but, rather, thrives as an opposition to these super structures identified by Chalk. Banjo is by no means monetarily successful, but the way he lives his life in the Ditch, with free artistic and self-expression, allows him to excel minus the constraints of Victorian masculinist expectations.

He cares not for earthly possessions and certainly not for capital gain as a result of imperial expansion. Instead, he immerses himself in the world of experience, including others on his fantastical and impressive journeys. Banjo best explains his position on masculinity when he discusses it with Bugsy: "A fellah doing that back home gotta show himself a man ehverytime. Him gotta come strutting swell and blowing big. He's gotta show he ain't nobody's ah-ah business" (160). He appreciates the liberal, sailor-intensive environment of Marseille, as it offers a break from the cultural expectations he experienced in the United States, as he describes in the quote. Judging by his frustration in the passage, he was expected to be physically strong to avoid conflict with other males. For him, the ideal image of man is one without attachments, whether they consist cultural, relationship or gendered ones. He allows himself to interact with people on the surface level, occasionally going further in friendship, as is the case with Ray and 
Latnah, but, mostly, he distances himself from the people surrounding him seemingly as a defense mechanism.

McKay offers another unique protest to Victorian, colonial ideals when he discusses the role of music in the Ditch. While empire, capitalism and exploitation are all concepts which segregate and divide, art, in this specific instance standing as music, acts as a unifying and culturally inclusive tool. McKay explores how the music of the ditch has mystical qualities, bringing all races and ethnicities together. Banjo, equipped with his own instrument, joins this magic and basks in the anti-imperialist sentiment, especially when McKay comments, "to Banjo, it had brought a unique feeling of satisfaction. He did not miss it, as he never missed anything rich that came within his line of living" (46). Since he lives his life as an active protest against ideals defined by Victorians, music stands as the highlight of this anti-imperialist lifestyle. The harmony of the Ditch is best explained when the focus of the tenants is on the music. Concerns about money, race, nationality, gender performance or sexual orientation are forgotten, and interest in artistic expression takes the place of those concerns. Even the narrator in this section abandons the position of neutral observer to join Banjo in his enthusiasm for musical collectivity. Anthony Reed observes, "Thus, men perform this authentic culture and create a culture among and for themselves" (Reed 760). Not only is culture expressed through this activity, individuality is given precedence and self-expression is signified. As Banjo plays less and less further into the novel, he seems to fall into a depression and separateness from his friends. The Ditch becomes an ugly place for him, devoid of art and music and instead full of racial, nationalistic, and masculinist societal functions.

His depression from not engaging in artistic pursuits results in problems of physical health. Finally, when he experiences the failure of his kidneys toward the end of the novel, he 
offers his crucial definition of masculinity, one seeming to bastardize and make uncanny the original Victorian masculine expectations: "but he bore his punishment bravely like a man - one who knows that he must take the consequences of spurning the sheltered, cramping ways of respectability to live like a reckless vagabond, who burns up his numbered days gloriously and dies blazing" (244). A sense of duty is present in this explanation, but this duty is not of any state or gender subscription. It is a duty to himself as an individual, to live as freely and rashly as possible with the intention of burning out. This concept would offend Kipling and his masculinist Victorians on a multitude of levels. McKay, as narrator, responds directly to this offense with, "No Victorian-long period of featured grief and sable mourning, no mechanicalpale graveside face, but a luxuriant living up from it, like the great jungles growing perennially beautiful and green in the yellow blaze of the sun over the long life-breaking tragedy of Africa" (322). Masculinity in this context is now unable to be deduced singularly as a result of the amalgamation of various cultural representatives: as Victorian masculinity concerned only middle-class white males on the verge of joining the colonial front, modernist masculinity includes numerically vast national, ethnic and social groups.

In Ray and Banjo, a continuation of Conrad's foundational effort in Heart of Darkness is present: while Conrad, a Polish writer, details Marlow's journey from the perspective of one affected by imperialism, McKay explores the perspective of one victimized, even tortured, by colonial sentiments. While Marlow is presumably allowed to live his life after the atrocities he has witnessed in the Congo, Ray and Banjo's utopian dream in the Ditch is abandoned, as they realize in the conclusion of the novel how that lifestyle is impossible to sustain. As victims of imperialism, they have to continue to live within the confines of the primitive or nativized 
stereotype by the dominant European paradigm, as McKay outwardly suggests in the novel's ending.

While Conrad strayed from critiquing Victorian ideals of maleness outwardly and viscerally, McKay in his presentation of the characters Ray and Banjo and the modernist utopia Marseille as their setting expounds that masculinity has become diluted and impossible to define singularly. Instead, as a global modernist he delivers a comprehensive, liberal understanding of masculine expression existing in the modern world. Through his offering of various, sometimes conflicting, definitions of masculinity, he ultimately claims that no single image of maleness can exist in the modern, colonial and postcolonial world, and, instead, many different versions of masculinity must be embraced. Whether it is the largely romanticized image of Banjo as a carefree, attachment-free vagabond living entirely for experience or the character Ray, who embraces his own femininity to balance his masculinity in critiquing empire, McKay concludes, like Harris, that several different versions of masculinity exist in the modern world, and each have to be considered equally. When each of these versions of masculine expression can coexist, the modernist post-imperial utopia in Marseille can be realized. Surely, both of these fledgling modernist masculine figures would offend and potentially disgust Kipling because of their betrayal of Victorian masculinist, imperial ideals. And McKay appears rather deliberate in attempting to create characters to accomplish that feat. 
Wilson Harris' Colonized Colonizer: An Exploration into Post Imperial Masculinities As a representative global modernist text, Wilson Harris' Palace of the Peacock offers crucial commentary on masculinity in an imperialist context. It takes the underlying themes found in Conrad's Heart of Darkness -- such as the effects on the psyche of the colonizer, the identity conflicts of the natives, and the overall feelings of despair surrounding the subject - and updates them through the unique perspective from the colonized position. Specifically, the character Donne in the novel presents critical commentary on the imperial process and its effects on masculine expression. Additionally, the crew aboard the ship, speaking from the troubling perspective of simultaneously having been colonized and continuing to colonize, reflect explicit modernist reactions to masculine gender constructions implemented by Victorian England. Harris, in a vein similar to Conrad, does not critique the masculinist principles expected in the imperialist thought process but, rather, provides numerous surreal examples of how these gender constructions continually fail and actively oppress. Additionally, as the tale takes place primarily on a voyage deeper and deeper into uncivilized terrain, the text mirrors Heart of Darkness' journey as a documentary of exploitation. Palace of the Peacock for these reasons stands today as a late and global modernist response to the inherent exploitative properties in empire and the effects that stem from them, employing the languages of both capitalism and Christianity as a means of critique.

Beginning with the pervasive character Donne, it is worth noting that he is not meant as much to be a caricature of the ideal imperialist defined by Kipling and explored by Conrad but, rather, an exaggeration. There are multiple reasons to explain this exaggeration, at least in the way he deals with his subjects aboard the ship and on his plantation and the captured Arawak woman. One detail that helps explain his hyperbolic cruelty arises in the color of his skin: as a 
native of Guyana with a typical dark complexion, Donne appears to be compensating. Having learned the principles and expectations of the colonist from Victorian England, which were originally set by figures like Kipling and Ruskin, he seems to be elevating his harshness for his conquered people as a way of making up for the fact that he is not white.

With this explanation, Harris gives a postcolonial response to Kipling's ideal imperialist as well as Conrad's Kurtz in the presentation of Donne. His masculinity is also exaggerated, ultimately undoing him. His declaration of intent early in the novel is as haunting as it is critical of colonial expectations, especially in the context of masculinity: "One has to be a devil to survive. I'm the last landlord. I tell you I fight everything in nature, flood, drought, chicken hawk, rat, beast and woman. I'm everything. Midwife, yes, doctor, yes, gaoler, judge, hangman, every blasted thing to the labouring people. Look man, look outside again. Primitive. Every boundary line is a myth. No-man's land, understand?" (Harris 22). This passage is a dense one, bountiful with information on Harris' views of masculinity in empire. First, the intense and visceral language, especially when he refers to the "primitive" or savage natives, plays on European parochial views of colonized peoples. In addition to appearing parochial, this passage is an overwhelmingly paternalistic one, regarding these conquered inhabitants essentially as children who are unable to perform basic duties. Second, Done inhabits a unique position: he exists in this text as both a native of Guyana, sharing his countrymen's dark complexion, while also carrying a heritage of colonial dominion and exploitation. In order for him to occupy this troublesome situation, he has to "be a devil" and stave off native opposition continually.

A familiar quality in this quote is the way in which guilt is present. The guidelines and expectations set forth in Kipling's “The White Man's Burden” contain this tinge of guilt as well, giving an illustration of a conflicted but accomplished colonist. Harris' passage explores these 
guidelines and gives a more accurate and explicit set of duties the colonist must perform in order to be successful. Donne in the quote has forsaken his identity, his humanity in order to be a "devil" suited to colonize more. Additionally, the use of the word "devil" is a rather appropriate and intentional one. As Kipling employed biblical rhetoric as a means of justifying or motivating imperial action, Harris uses the same vocabulary but instead as a way of critiquing it. While Kipling referred to the colonized people as devils, Harris turns that coin and explains how the colonist must be placed in that position.

His use of the word "devil" repeatedly throughout the text marks the toxic effect of exploitation of native peoples on his appearance both externally and internally. A specific instance to help explain this notion appears when the narrator describes how the journey, which can stand as a metaphor for the critique of colonial progress, "aged him into looking the devil himself' (49). With this information, the reader can gather that his hyper-masculine way of approaching imperialist action has physically, emotionally and mentally deformed him. A character who meets a similar fate appears in Conrad's Kurtz, as he, too, ultimately succumbed to the intense masculinist pressures applied by the institution of empire.

The psychology of Donne is worth exploring. He is aware of his inhumane actions throughout the novel but continues committing them. By the end of the journey to the Palace of the Peacock, where all of the crew realizes they have been dead all along, Donne is perplexed as to why his own humanity has been stripped and why he, in a certain nihilistic fashion, feels nothing internally. His confession to the crew denotes this internalized violent nature: "I hate myself sometimes, hate myself for being the most violent taskmaster - I drive myself with no hope of redemption whatsoever and I lash the folk" (50). In this specific monologue, he refrains from blaming any certain entity for making him commit the atrocities he has performed. Instead, 
he complains about feeling guilty for the exploitation he has overseen. Though in this moment he expresses his feelings clearly and what appears to be genuinely, he immediately attempts to cover this honesty by outwardly and offensively damning the natives he actively exploits. Though this quick transition into blaming the people he is enslaving may come across as making the original confession illegitimate or ingenuous, the fact that he rose to admit these kinds of feelings shows that the subjects are at least on his mind. Additionally, his frankness and confiding tone, at least in the early stage of the declaration, seems an honest and confiding one. The abrupt transition could help explain a comprehensive frustration he has surrounding his own masculine expression, as his tone shifts dramatically to one of bitterness and inflammation.

Donne, whose name is based on the metaphysical English poet John Donne, implying further his foundation based out of the English tradition and culture, utilizes the language of Kipling throughout the text both to motivate the crew and justify his actions. An example of this motivating language can be found in the way he addresses the exhausted, scared crew: "We can catch up and repair our fortunes. They'll lead us home safely and we'll cultivate our fields and our wives"' (83). The non-committal, empty reassurance offered here should appear as blank and unpromising as one delivered by Kipling. Though not out of the biblical tradition, the language is still imperial. Additionally, in a manner that seems to reference Kipling directly, in one of his monologues where he damns the act of colonizing and the people he colonizes, he admits, "Some weight and burden I confess frankly" (50). He states this sentiment after he reveals the psychology of the colonist in plain terms, and how expansion has affected his mental health and masculinity. In using the term "burden," Harris calls out Kipling's inconclusive and exploitative poem "The White Man's Burden" as offering little else than instructions for hate and violence. Donne, as a character who has adopted these guidelines to live his life as a colonist, 
sacrifices his humanity and finds himself resultantly empty upon reaching the Palace of the Peacock.

In presenting a character like Donne, Harris criticizes the continued code of masculinist ethics implemented by British colonizers. Though this sentiment is never expressed as explicitly, the notion is explored repeatedly in Harris' signature surreal and dense prose. A prime example of this continuation of skewed ideals appears with the passage, "All were signs of address from a past dead investment and history with its vague pioneering memories that were more their burden than his" (70). Though this quote might not pertain exclusively to Donne, it contains the psychological effects of imperialism on both the colonized and the unique nativized colonizer. The British, in implanting their culture and traditions, also implemented a masculine expectation to continue expanding, to continue colonizing, and to continue exploiting, much to the detriment of the understandably confused and pressured natives of Guyana.

The brotherly relationship in the novel is an important one. The unnamed Dreamer and Donne share few resembling characteristics. While Donne is aggressive, brutal, and declarative, the Dreamer is instead passive, distant, and inward. Both represent the top tier of Guyana's social hierarchy, though, with Donne occupying the wealthy plantation owner and colonist roles and the Dreamer functioning as an intellectual elite. Their relationship throughout the text is a stressful one, as Donne reveals his most monstrous motivations surrounding his imperial endeavors to his brother. What frightens the brother most is that he sees certain aspects of his own human condition, his own masculinity, in the image of his brother: "I saw him now for the first faceless time as the captain and unnatural soul of heaven's dream; he was myself standing outside of me while I stood inside of him" (26). The narrator fails to speak his opinion on matters throughout the text, and these instances arise when he is about to be critical of Donne's 
actions or thought process surrounding the natives of Guyana. The Dreamer is aware of Donne's brutality and hyper-masculine code of ethics derived from imperial thinking, and he is terrified that he, too, bears some of his identity traits.

This presence of a relationship between brothers presents a keen insight into the mind of the typical Guyana inhabitant of the time. The binary of these two characters sets up the conflict many affected native people of Guyana faced: coming out of a recent tradition of colonialism and exploitation from the British, what actions should follow? Caribbean Literature scholar Barbra Webb offers commentary on the matter, and specifically the presence of the relationship of the brothers, with the quote, "The principle of duality, seen in the contrasting figures of the two brothers, is extended to all levels of the narrative. Donne's alienation is estrangement from self as well as estrangement from those he seeks to rule" (Webb 68). Because the Dreamer as the first person narrator blatantly disappears for a substantial portion of the novel, it can be additionally gathered that he, too, loses himself in the journey.

This emptiness Donne faces is the psychological effect from colonization that Harris explores, and juxtaposing that situation with that of his brother is important when considering the novel as a whole. By the end of the text, the crew has reached the Palace of the Peacock, dying twice and reemerging in an Edenic setting. These two specific characters have changed by this point: Donne has realized the detrimental effects on his own psyche as a direct result from the cruelty in his colonizing affairs, and the Dreamer has realized his importance in pointing out the injustices of the brutality. Donne's consciousness appears in its most visceral way in the quote, "It was the unflinching clarity with which he looked into himself and saw that all his life he had loved no one but himself' (Harris 107). Harris comments that this is the typical subconscious thought process of the colonizer, and that the act is an entirely selfish one. 
Both brothers, with one actively brutalizing people and the other standing idly by, offer critical commentary on the cultural climate of Guyana at that time. Harris makes the statement, then, that if Guyana is to succeed independently of its British colonizers, it must consider all peoples of the nation equal. This notion is better explained in the way Harris describes the relations of the crew upon reaching the Palace of the Peacock. Joyce Sparer Adler, a contemporary scholar on Harris, claims, "Even Palace of the Peacock, which is so visually a depiction of Guyana's interior, is about man in a world where the various parts of himself are divided from, and forgotten by, each other, in generation after generation" (Adler 39). The significance of this quote lies in the pertinence to the novel's crewmembers: though they share the same nationality and background, little else ties them together. Additionally, the motivation for getting to know one another is simply not there. When at the Palace, though, a certain harmony, an accord is reached because all of the crew, including Donne, the Dreamer, characters like Cameron, Old Schomburgh, Vigilance and Carroll, are all on the same plane, both literally and metaphorically.

Before the significance of the harmony can be adequately discussed, though, examining the crew and the effects of imperialism on their actions and their masculinity is important. As a preface, the members of the crew, with the exception of Old Schomburgh, are mostly interchangeable. Their personalities are similar, and their backgrounds share a common element: from a young age, their masculinity has been affected by a difficult attempt to balance traditions of Guyana and newly established imperial traditions. Donne, the Dreamer, and Old Schomburgh share these conflicting backgrounds, and Harris makes the point to show their commonality: "The whole crew was one spiritual family living and dying together in a common grave out of which they had spring again from the same soul and womb as it were" (Harris 39). This passage 
is a substantial one because the crew, for the most part, shares a common background, at least in terms of geography. Though they might have different views of British occupation, imperialism, and the direction Guyana should go without a British presence, they all share the same home in Guyana and, as Harris repeats throughout the novel, the same complexion.

One crewmember, specifically, is cast in a particularly troublesome light earlier in the text. Cameron, like the rest of the crew with the exception of Donne, is certainly not an intellect and uses broken English in conversation. When Harris describes his goal of being a fisherman as "a gross exaggeration of his desires and intentions, an enormous extension and daydream to which hard and strong and tough men are curiously subject though they fear and seek to reprove themselves for thinking in such a light" (40), he means to comment on the effect imperial tendencies have had on his psychology. Rather than committing to being a fisherman wholeheartedly, his ambition is limited. Two obstructions to his goal are his fear of being scolded by some nameless or figureless superior, in the same vein of a slave being afraid of a slave master or the colonized being afraid of the colonizer, and his internalization of being too weak and unable to match the strength of the idealized, Victorian imperialist before him. Either way, his personal limitations at this point are obviously tied to imperial and masculine conditions.

As the crew travels deeper along the river in search of Mariella, they frequently believe their actions to be amoral and unethical. The crew comes to this conclusion much sooner than their leader Donne, but even then it is too late. Commenting on the continued unique use of the world "devil," they associate it with an unjustified guilt. This notion differs from both Kipling's and Donne's conception of the term, as the former considers the colonized peoples "devils," while the latter considers himself, as a colonizer, a "devil." Harris explains the crew's awareness 
of itself with the passage, "Rather it seemed to them only too clear that the past would always catch up with them - when they least expected it - like a legion of devils" (84). With this last interpretation of the term "devil" and its effects on the psyche of the crewmen, the reader can gather how empire and the act of colonization has done serious psychological damage.

Upon entering the Palace, though, these differences in masculinity in an imperial context are leveled, allowing each of the characters to exist in a world without these expectations. As Donne has recognized his own emptiness as a direct result of his colonizing, the crew, too, has realized the negative outcomes of colonialism. The catharsis and realignment of ideals is perfectly captured when Harris states in the final chapter how, "the command to the starred peacock who was instantly transported to know and to hug to himself his true invisible otherness and opposition, his true alien spiritual love without cruelty and confusion in the blindness and frustration of desire" (116). This passage explains how the crew has realized the faults in each other and how they have embraced those faults. In order for this social equality and harmony to be reached in this dream-like state in the Palace, the conflicts or oppositions require addressing, and many of those disagreements arose from issues surrounding lingering British expansionist values and masculinity disparities in an imperial context, or in this instance a postcolonial environment. Adler joins this conversation when she states, "The unity which man, represented by the crew, had been forever seeking, the self-fulfillment in the reunion of the various parts of himself, had always been his to take and make part of life; man has eternally possessed this potentiality" (39). To better explain this sentiment, Harris' passage explains the coming to terms with the desire to colonize and exploit others as an offshoot of masculinist ethics imposed by the British during their reign in Guyana, and as a result of the settling of those desires, the crew can live together despite their personality differences. 
Though his primary intention was potentially not to dwell on the issue of masculinity as being detrimentally affected by imperialist conditions, Wilson Harris inevitably addressed the matter when critiquing the lasting effects of British colonialism in Guyana. His critique, like Conrad's, is not outright explicit or direct, but certainly it appears more biting when moments of clarity arise. His dense metaphysical and surreal language, his non-linear plot, and his difficult characterizations are in themselves critiques on the British novel, complementing the protest against the defined tradition. The character Donne fully encapsulates the lingering British Victorian masculinist expectations in Guyana at that time, and through his epiphany of realizing his own emptiness as a direct result of conducting himself in a hyper-masculine manner and exploiting conquered peoples, Harris combines his critique of empire with a critical look at masculinity. Kipling's ideal colonist here is debunked with the analysis of Donne, as these masculinist ethics will ultimately lead to emptiness and despair. 


\section{Closing Remarks}

Studies on gender relations and constructions today analyze elements of contemporary society and, subsequently, criticize cultural, artistic and institutional forms of sexism and social injustice. In pointing out how these problems exist, many dissect the problem in its current context and discuss how the problem affects those in that setting. By looking at pieces of literature and exploring those pieces in their own cultural, historical contexts, studies on gender in those times can be utilized to explain why the kind of social constructions of gender exist today.

Through that reasoning, the examination of Kipling's “The White Man's Burden” and “The Man Who Would Be King,” Conrad’s Heart of Darkness, McKay’s Banjo, and Harris' Palace of the Peacock in how each of them relate in the realm of masculine expression as a result of imperialism is a significant practice. Imperialism and modernity have impacted masculinity irrefutably. What was at one time considered indelibly singular, the concept of masculinity has evolved substantially since Kipling expressed his Victorian ideals surrounding maleness. Though these ideals lingered throughout the twentieth century, and still exist to a degree today, the modernists reacting to these gender constructions were motivated by debunking it. Conservative Victorian society existed through many social injustices, and resultantly modernists aimed to reveal and attack them.

My project was designed to explore the ways writers who were affected by imperialism conveyed the results of colonial tendencies on their ranging masculinities. Conrad reports his criticism from a position of being affected by imperialism, while McKay and Harris go a step further to detail the effects on their masculinities, among other things, from a victimized position. Because these two writers appear as victims of Victorian exploitation through 
expansion, they could never fir the exact mold required of men of the time: what this statement means is these writers would never fit into the macho, racist, elitist set of expectations applied to men from Victorian England. Instead of attempting to operate out of this singular, unfair range of expectations surrounding masculine expression, both McKay and Harris contested the issue and produced an image of maleness that encompassed many other lifestyles. As the field of modernism in a global context is still in a seemingly fledgling state, reporting on the connections between these writers is a necessary practice - one that requires further attention to previously ignored writers on previously unimportant subjects. As more literary analysis develops out of a focus on this field, more postcolonial criticism can be applied to the situations of writers victimized or brutalized by the exploitative and tumultuous conditions of colonialism.

Kipling defined the ideal Victorian exhibition of masculinity as staunch, wholesome and able to rationalize mass exploitation and violence. Nationalistic and religious overtones are strongly connected to this definition, too. His image of maleness is considered today as a racist, violent, and hyper masculine one, and the early and global modernists, like Conrad, McKay and Harris, who responded negatively and outwardly were brave for being so oppositional. They helped to dilute Kipling's ideal Victorian man into many sprawling definitions of manhood and masculine expression, as evident from their works. Though they did not abolish the Victorian image entirely, their varyingly progressive stances on gender proved to provide a more openended manner of accepting different forms masculinities. 


\section{Works Cited}

Adler, Joyce Sparer. Exploring the Palace of the Peacock: Essays on Wilson Harris. Kingston: U of the West Indies P, 2003. Print.

Brebah, Raymond. "Conrad In Context: Heart Of Darkness And "The Man Who Would Be King." Conradiana 42.1/2 (2010): 75-80. Academic Search Premier.

Chalk, Bridget T. "Sensible Of Being 'Étrangers'": Plots And Identity Papers In "Banjo." Twentieth Century Literature 55.3 (2009): 357-377.

Clatterbaugh, Kenneth. Contemporary Perspectives on Masculinity: Men, Women, and Politics in Modern Society.” Boulder: Westview P, 1990. Print.

Conrad, Joseph. Heart of Darkness. The Norton Anthology of English Literature. Ed. Stephen Greenblatt. New York: W.W. Norton \& Company, Inc., 2012. 1951-2012. Print

Greenblatt, Stephen, ed. The Norton Anthology of English Literature. New York: W.W. Norton \& Company, Inc., 2012. Print.

Hampson, Robert. "Kipling and the fin-de-siecle." The Cambridge Companion to Rudyard Kipling. Ed. Howard J. Booth. New York: Cambridge UP, 2011. 7-23. Print.

Harris, Wilson. The Guyana Quartet. London: Faber and Faber Limited, 1985. Print. Holcomb, Gary Edward. 'The 'Rude Anarchy' of 'Black Boys' in Banjo.” Claude McKay, Code Name Sasha: Queer Black Marxism and the Harlem Renaissance. Gainesville: University Press of Florida, 2007. 139-170. Print.

Kestner, Joseph A. Masculinities in British Adventure Fiction, 1880-1915. Burlington: Ashgate Publishing Company, 2010. Print. 
Kipling, Rudyard. "The Man Who Would Be King.” The Norton Anthology of English

Literature. Ed. Stephen Greenblatt. New York: W.W. Norton \& Company, Inc., 2012. Orig. Pub. 1888. 1853-1857. Print.

Kipling, Rudyard. “The White Man's Burden.” The Norton Anthology of English Literature. Ed. Stephen Greenblatt. New York: W.W. Norton \& Company, Inc., 2012. Orig. Pub. 1899. 1880-1882. Print.

McKay, Claude. Banjo. Orlando: Harcourt Brace \& Company, 1957. Print.

Porter, Bernard. "Cutting The British Empire Down To Size." History Today 62.10 (2012): 2229. Web. 24 Apr. 2013.

Reed, Anthony. "A Woman Is a Conjunction" The Ends Of Improvisation In Claude McKay's Banjo: A Story Without A Plot." Callaloo 36.3 (2013): 758-772.

Roberts, Andrew Michael. "Epistemology, Modernity, and Masculinity: 'Heart of Darkness."” Conrad and Masculinity. New York: St. Martin's Press, Inc., 2000. 118-136. Print. Ruppel, Richard J. Homosexuality in the Life and Work of Joseph Conrad: Love Between the Lines. New York: Taylor and Francis, 2008. Print.

Saha, P.K. "Conrad's Heart Of Darkness." Explicator 50.3 (1992): 155-159. Web. 26 Apr. 2013.

Webb, Barbara J. Myth and History in Caribbean Fiction: Alejo Carpentier, Wilson Harris, and Edouard Glissant. Amherst: The U of Massachusetts P, 1992. Print.

White, Andrea. "Conrad and Imperialism." The Cambridge Companion to Joseph Conrad. Ed. J. H. Stape. New York: Cambridge, 1996. 179-202. Print. 